\title{
Viruses, prokaryotes and biochemical composition of organic matter in different types of mucilage aggregates
}

\author{
Lucia Bongiorni ${ }^{1}$, Monica Armeni ${ }^{1,2}$, Cinzia Corinaldesi ${ }^{1}$, Antonio Dell'Anno ${ }^{1}$, \\ Antonio Pusceddu ${ }^{1}$, Roberto Danovaro ${ }^{1, *}$
}

${ }^{1}$ Department of Marine Science, Polytechnic University of Marche, Via Brecce Bianche, 60131 Ancona, Italy

${ }^{2}$ Present address: EcoTechSystems Ltd, Piazza del Plebiscito 21, 60131 Ancona, Italy

\begin{abstract}
It has been hypothesised that several microbial processes contribute to mucilage formation and transformation. However, to date, none of these mechanisms have been consistently tested using different types of mucilage. We investigated the biochemical composition and the microbial activities occurring in 9 different types of mucilage aggregates (macroflocs, stringers, cobwebs, ribbons, stringers/cobwebs clouds, big creamy surface layer, false bottoms and anoxic false bottoms) collected during summer 2000, 2002 and 2003 in the Adriatic Sea. Larger and aged aggregates, characterized by the accumulation of carbohydrate and a low lipid fraction, displayed significant biochemical differences when compared with younger aggregates. Prokaryote abundance, C production and extracellular enzymatic activities increased from small to medium-sized aggregates (corresponding approximately to mid life span) while they decreased in larger (and aged) aggregates. The highest prokaryotic $\mathrm{C}$ production and enzymatic activities were coupled with highest viral abundance. In mucilage displaying the highest viral abundance a reduced incorporation of enzymatically degraded $\mathrm{C}$ into prokaryote biomass was observed. This result suggests a potential involvement of viruses in the impairment of the microbial loop functioning in marine aggregates. Applying a multivariate analysis to the microbial variables, 3 stages of mucilage life span can be identified: (1) an early stage characterized by a large prokaryote colonization of the aggregate and DOM accumulation; (2) a mature stage characterized by a decreased capability of incorporating degraded C into prokaryote biomass and high viral abundance and (3) an aged stage characterized by the decrease in both viral and prokaryote abundance and prokaryote activity. These results provide new insights into the microbial ecology of marine aggregates and the processes influencing their life span.
\end{abstract}

KEY WORDS: Mucilage aggregates $\cdot$ Biochemistry $\cdot$ Prokaryotes $\cdot$ Virus $\cdot$ Adriatic Sea

\section{INTRODUCTION}

Large marine aggregates, known as 'marine snow', are ubiquitous components of aquatic ecosystems (Simon et al. 2002). Mucilage aggregates are considered to be an exacerbated and evolving stage of the marine snow (Herndl \& Peduzzi 1988, Giani et al. 1992, Herndl et al. 1992, Fogg 1995). The frequency of appearance of massive mucilaginous aggregates is increasing in the oceans worldwide, particularly in the
Mediterranean Sea (Gotsis-Skretas 1995, Innamorati 1995), sectors of the Pacific Ocean (Steinberg et al. 1997) and the North Sea (Riebesell 1992), and, in recent years, along US coasts (such as in California; Alldredge et al. 2002).

There is a converging opinion that the synergic effects of biological and physico-chemical factors might contribute as causative agents to the formation and persistence of marine mucilage. However, it has been hypothesized that different causes are directly 
responsible for the development of this phenomenon. Among these, recent studies have identified (1) altered inorganic nutrient supply and stoichiometric N:P ratios with consequent physiological stress of microalgae (Degobbis et al. 1999), (2) enhanced production of algal exudates associated to changes in grazing pressure (Pajdak-Stós et al. 2001), (3) malfunctioning of the microbial loop (Herndl et al. 1992, Danovaro et al. 2005) and (4) viral infection of bacterioplankton followed by cell lysis and release of DOM (Azam 1997).

The hypothesis based on the malfunctioning of the microbial loop suggests the presence of an uncoupling between organic matter degradation and its utilization. This could lead to the massive accumulation of polysaccharides and dissolved compounds in the water column and, then, to their coalescence (a prerequisite for mucilage formation; Azam et al. 1999).

The hypothesis based on viral shunt is not necessarily alternative to the former, as the cell lysis due to viral infection contributes to the release of intracellular dissolved organic compounds in the surrounding waters (Peduzzi \& Weinbauer 1993, Weinbauer \& Peduzzi 1995, Weinbauer et al. 1995, Baldi et al. 1997, Shibata et al. 1997). At the same time, it has also been hypothesized that viral infection, by releasing bioavailable DOM, could contribute to sustaining prokaryote growth, and consequently to accelerating mucilage degradation (Bratbak et al. 1990).

Stachowitsch et al. (1990) and Precali et al. (2005) identified and described different types of mucilage aggregate: macroflocs, stringers, cobwebs, ribbons, clouds, big creamy surface layers, gelatinous surface layers and false bottoms. These authors also related differences in shape, size (from a few millimeters to several meters), position and persistence in the water column, and effects on the benthos to different stages of the mucilage life span. Moreover, there is evidence that different marine aggregates display differences in their biochemical composition and microbial abundance and activities (Azam \& Long 2001, Kiørboe 2001, Del Negro et al. 2005).
In the present study, we tested the hypothesis that the different types of mucilage aggregates are characterized by significant differences in their biochemical composition and degradation rates as a result of changes in the virus-prokaryote relationships, and that such changes are related to the changes occurring in the mucilage during its life span. We addressed 4 main questions: Are there differences in degradation rates in different types of aggregates? And, if so, are these differences related to their different biochemical composition? Do the virus-prokaryote interactions change in different types of aggregates? How do viruses and prokaryote activities influence the dynamics of mucilage aggregates?

\section{MATERIALS AND METHODS}

Study site, sampling and sample processing. Mucilage aggregates were collected during summer 2000, 2002 and 2003 at 9 different stations in the Adriatic Sea (Table 1). Aggregates were spotted by an underwater video camera mounted on a remotely operated vehicle. For each mucilage type, sub-samples from 3 separate aggregates were collected by SCUBA divers using 50 to $1500 \mathrm{ml}$ sterile polyester syringes at depths ranging from 0 to $20 \mathrm{~m}$. Ambient seawater samples were synoptically collected using 101 Niskin bottles deployed at the same depth at which aggregates were sampled.

Mucilage aggregates were visually classified according to their morphology (Stachowitsch et al. 1990, Precali et al. 2005) into 8 different stages: macroflocs, stringers, stringers/cobwebs, cobwebs, ribbons, clouds, creamy surface layer and false bottom (Table 1). In addition, we also analyzed 'false bottom aggregates' from sediments characterized by anoxic conditions ('anoxic false bottom'). Once on board, mucilage samples were centrifuged at $3000 \mathrm{rpm}$ $(1200 \times g$ for $15 \mathrm{~min}$ at in situ temperature).

For the biochemical analyses, aliquots of the pellets were immediately frozen at $-20^{\circ} \mathrm{C}$. For prokaryote and

Table 1. Location of the sampling stations and main characteristics of mucilaginous aggregates (sizes and shapes according to Stachowitsch et al. 1990 and Precali et al. 2005) collected in the Adriatic Sea

\begin{tabular}{|lccl|}
\hline Type of aggregate & Latitude $(\mathrm{N})$ & Longitude $(\mathrm{E})$ & \multicolumn{1}{c|}{ Size $(\mathrm{m})$ and shape } \\
\hline Macroflocs & $44^{\circ} 40^{\prime}$ & $12^{\circ} 94^{\prime}$ & $0.01-0.05 \mathrm{~m}$, subspherical \\
Stringers & $43^{\circ} 90^{\prime}$ & $13^{\circ} 44^{\prime}$ & $0.01-0.25 \mathrm{~m}$, elongated, comet-shaped \\
Stringers/cobwebs & $44^{\circ} 33^{\prime}$ & $14^{\circ} 08^{\prime}$ & Elongated, web-like aggregates \\
Cobwebs & $44^{\circ} 72^{\prime}$ & $13^{\circ} 80^{\prime}$ & $10 \mathrm{~s}$ of meters, web-like aggregates \\
Ribbons & $43^{\circ} 90^{\prime}$ & $13^{\circ} 44^{\prime}$ & $0.1-1 \mathrm{~m}$, elongated \\
Clouds & $43^{\circ} 80^{\prime}$ & $13^{\circ} 28^{\prime}$ & $0.5-4 \mathrm{~m}$, elongated, subspherical \\
False bottom & $44^{\circ} 43^{\prime}$ & $13^{\circ} 04^{\prime}$ & Dense layer of stringers and macroflocs at pycnocline \\
Anoxic false bottom & $43^{\circ} 34^{\prime}$ & $13^{\circ} 34^{\prime}$ & Anoxic dense layer at pycnocline \\
Creamy surface layer & $43^{\circ} 80^{\prime}$ & $13^{\circ} 28^{\prime}$ & Stringers formed, creamy layer floating at or below surface \\
\hline
\end{tabular}


viral counts, additional aliquots of the pellet were diluted (1:10) with $0.02 \mu \mathrm{m}$ filtered (virus-free) ambient seawater, incubated with pyrophosphate $(0.01 \mathrm{M})$ for 15 min (Epstein \& Rossel 1995) and sonicated 3 times (Branson Sonifier 2200; $60 \mathrm{~W}$ for $1 \mathrm{~min}$ ). After additional dilution (up to 500 times) with virus-free seawater, sub-samples were filtered onto a $0.02 \mu \mathrm{m}$ poresize filter (Anodisc; diameter, $25 \mathrm{~mm} ; \mathrm{Al}_{2} \mathrm{O}_{3}$ ), stained with $20 \mu \mathrm{l}$ of SYBR Green I (15 min) and stored at $-20^{\circ} \mathrm{C}$ until analysis (within $2 \mathrm{wk}$ ). Ambient seawater subsamples $(100 \mu \mathrm{l})$ were filtered and processed as described above.

For the analysis of extracellular enzymatic activities and prokaryote $\mathrm{C}$ production, aliquots of ambient seawater and of the pellets (previously diluted up to 400 times with $0.02 \mu \mathrm{m}$ pre-filtered seawater) were immediately processed on board as described below.

Biochemical composition of aggregates. Photosynthetic pigments (chlorophyll a [chl a] and phaeopigments) were analyzed fluorometrically according to Lorenzen \& Jeffrey (1980) after extraction of $1.0 \mathrm{ml}$ pellet of each aggregate with $90 \%$ acetone $(24 \mathrm{~h}$ in the dark at $4^{\circ} \mathrm{C}$ ). Chloroplastic pigment equivalents were defined as the sum of chl $a$ and phaeopigments (Fabiano \& Pusceddu 1998).

Total protein concentration of mucilage was determined according to Hartree (1972), modified by Rice (1982) and expressed as bovine serum albumin equivalents. Total carbohydrates were analyzed according to Dubois et al. (1956), Gerchacov \& Hatcher (1972) and expressed as glucose equivalents. Total lipids were extracted from the mucilage by direct elution with chloroform-methanol (1:1 v/v) according to Bligh \& Dyer (1959), then determined according to Marsh \& Weinstein (1966) and expressed as tripalmitine equivalents.

For each biochemical assay, blanks were obtained using pre-combusted mucilage samples $\left(450^{\circ} \mathrm{C}\right.$ for $\left.4 \mathrm{~h}\right)$ and concentrations were normalized to mucilage volume.

Carbohydrate, protein, and lipid concentrations were converted into carbon equivalents using the conversion factors $0.40,0.49$, and $0.75 \mathrm{mg} \mathrm{C} \mathrm{mg}^{-1}$, respectively, obtained from the elemental analysis of the standard utilized (Fichez 1991). The sum of protein, carbohydrate and lipid carbon equivalents were reported as biopolymeric organic carbon (Pusceddu et al. 2003).

Viral and prokaryote abundance. Prokaryote and viral counts were carried out as described by Noble \& Fuhrman (1998), using epifluorescence microscopy (Zeiss Axioplan; magnification, $\times 1000$ ) and examining 10 to 20 microscope fields and at least 400 prokaryote cells and virus-like particles for each filter.

Prokaryote biovolume (as maximal length and width) was estimated using a micrometer ocular assigning prokaryote cells to different size classes (Palumbo et al. 1984), and was converted into carbon

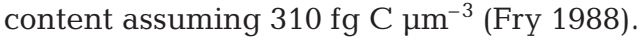

Extracellular enzymatic activities. Extracellular enzymatic activities (aminopeptidase, $\beta$-glucosidase and alkaline phosphatase) in aggregates and ambient seawater were determined by cleavage of artificial fluorogenic substrates (L-leucine-4-methylcoumarinyl7-amide, Leu-MCA; 4-methylumbelliferone- $\beta$-D-glucopyranoside, Glu-MUF; and 4-MUF-P-phosphate, MUF-P, respectively; SIGMA) at saturating concentrations (Hoppe 1993). Saturating concentrations of artificial substrate analogs, evaluated from saturation curves obtained separately for ambient seawater and all types of aggregates (data not shown), were $200 \mu \mathrm{M}$ for Glu-MUF and Leu-MCA and $50 \mu \mathrm{M}$ for MUF-P. Measurements of enzymatic activities were carried out on a final volume of $5 \mathrm{ml}$ by adding artificial fluorogenic substrates.

Blanks for mucilage samples and ambient seawater were obtained from previously autoclaved samples and from $0.02 \mu \mathrm{m}$ filtered seawater. Incubations were performed in the dark at in situ temperature for $1 \mathrm{~h}$ (enzymatic activities increased linearly with time up to $3 \mathrm{~h}$ ). After incubation, supernatants obtained from mucilage samples previously centrifuged (3000 rpm [1200 × g], $5 \mathrm{~min}$ ) and ambient seawater were analyzed fluorometrically (at $380 \mathrm{~nm}$ excitation, $440 \mathrm{~nm}$ emission for Leu-MCA and $365 \mathrm{~nm}$ excitation, $455 \mathrm{~nm}$ emission for Glu-MUF and MUF-P) using a Shimadzu RS-1501 fluorometer. Fluorescence was converted into nmol of hydrolyzed substrate using calibration curves obtained from standard solutions of 7-amino-4-methylcoumarin for Leu-MCA and of 4-methylumbelliferone for both Glu-MUF and MUF-P. The amount of hydrolyzed substrates was normalized to the incubation time and the volume of pellet or ambient seawater. Activities are hence reported as nmol of substrate released $\mathrm{ml}^{-1} \mathrm{~h}^{-1}$. Aminopeptidase and $\beta$-glucosidase activities were converted into equivalents of $\mathrm{C}$ mobilized assuming that $1 \mathrm{nmol}$ of substrate hydrolyzed enzymatically corresponds to $72 \mathrm{ng}$ of mobilized C (Crost 1991).

As all incubations were made using saturating concentrations of fluorogenic substrates, the measured activities represented the potential rather than the actual rates.

Prokaryote carbon production. Prokaryotic C production (PCP) was determined by ${ }^{3} \mathrm{H}$-leucine incorporation according to Smith \& Azam (1992). Triplicate sub-samples of diluted pellets and ambient seawater $(1.7 \mathrm{ml})$, and 2 blanks for each item (added with 100\% trichloroacetic acid, TCA), were incubated with ${ }^{3} \mathrm{H}-$ leucine (final concentration, $20 \mathrm{nM}$ ) at in situ temperature for $1 \mathrm{~h}$ in the dark. The concentration of $20 \mathrm{nM}$ was selected on the basis of saturation curves obtained 
separately for ambient seawater and all types of aggregates. The same ${ }^{3} \mathrm{H}$-leucine concentration was utilized previously (Del Negro et al. 2005), thus allowing a proper comparison with literature data. After incubation, all samples were added with $100 \%$ trichloroacetic acid (TCA; final concentration, 5\%) and processed as described by Smith \& Azam (1992), before scintillation counting. The following equation was used for calculating PCP:

$$
\mathrm{PCP}=\mathrm{LI} \times 131.2 \times(\% \text { Leu })-1 \times(\mathrm{C} / \text { protein }) \times \mathrm{ID}
$$

where $\mathrm{LI}$ is the leucine incorporation rate $\left(\mathrm{mol} \mathrm{ml}^{-1} \mathrm{~h}^{-1}\right)$, 131.2 is the molecular weight of leucine, \% Leu is the fraction of leucine in protein (0.073), C/protein is the ratio of cellular carbon to protein (0.86), and ID is the isotope dilution assuming a value of 2 (Kirchman 1993).

Prokaryote efficiency in using the mobilized $\mathrm{C}$ source was estimated as the ratio of prokaryote $\mathrm{C}$ production to $\mathrm{C}$ potentially mobilized enzymatically.

For each microbiological variable, the enrichment factor (EF) was calculated as the ratio between concentration or abundance in mucilage aggregates and concentration or abundance in the surrounding seawater.

Statistical analyses. Differences between mucilage aggregates in terms of biochemical composition and microbial variables were assessed by means of 1-way analysis of variance (ANOVA). In order to highlight significant differences among group average, a posthoc Tukey's comparison test for homogeneous groups was performed when significant differences were observed. Multidimensional scaling (MDS) analyses were also performed on all biochemical variables analyzed (proteins, lipids, carbohydrates, chlorophyll and phaeopigment concentrations) and microbial parameters (viral and prokaryote abundance, prokaryote biomass, carbon production, $\beta$-glucosidase, aminopeptidase and alkaline phosphatase activities) to ordinate mucilage types. The significance of identified clusters was tested using ANOSIM, whereas variables responsible for clustering were determined by means of SIMPER. All multivariate analyses were carried out with PRIMER 5.0.

\section{RESULTS}

Concentrations of proteins, carbohydrates, lipids, chl $a$ and phaeopigments, viral abundance, prokaryote abundance, biomass and $\mathrm{C}$ production, and extracellular enzymatic activities are reported in Table 2. Significant differences among the aggregate types were observed for all variables (ANOVA, $\mathrm{p}<0.001$ for all). The outputs of the post-hoc Tukey's comparison test for homogeneous groups for the whole set of variables are reported in Table 2 .

\section{Biochemical composition}

In all aggregates, carbohydrates represented the dominant biochemical fraction (on average $70 \%$ of biopolymeric C), followed by proteins (18\%) and lipids $(12 \%)$. Different biochemical compounds displayed different patterns among aggregates.

Anoxic false bottom contained 1.5-fold higher protein concentrations than creamy surface layer, which in turn displayed significantly higher concentrations than ribbons, clouds, stringers and false bottom followed by all other aggregates. Creamy surface layer and false bottom contained ca. 2-fold higher carbohydrate concentrations than ribbons and clouds, which in turn displayed significantly higher carbohydrate concentration than all other aggregates. Lipid concentrations up to ca. 1.5- to 2-fold higher were found in creamy surface layers and stringers than in macroflocs, false bottom and anoxic false bottom, which showed higher lipids then all other aggregates. Cobweb-like mucilage showed the highest chl $a$ and phaeopigment concentrations. In all types of aggregate, phaeopigments were much higher than chl a concentrations (chl a:phaeopigment ratio ranging from 0.4 to 0.5 ).

Protein contribution to biopolymeric $\mathrm{C}$ ranged from 8 to $46 \%$ and was significantly highest in anoxic false bottom aggregates than in the other aggregates (Tukey's test, $\mathrm{p}<0.05$ ). The carbohydrate fraction (range 45 to $87 \%$ of biopolymeric C) was significantly higher in false bottom, creamy surface layer, clouds and ribbons than in the other aggregates (Tukey's test, $\mathrm{p}<0.05$ ). Lipid contribution to biopolymeric $\mathrm{C}$ ranged from $2 \%$ in clouds to $23 \%$ in macroflocs and was significantly higher in macroflocs and stringers than cobwebs and stringers/cobwebs, which in turn displayed higher values than in the other aggregates (Tukey's test, $\mathrm{p}<0.05)$.

\section{Prokaryote abundance, biomass and production and viral abundance}

Significantly higher prokaryote abundance and biomass values were measured in clouds and false bottom aggregates, whereas higher values of PCP were found in ribbons (Table 2). Viral abundance was ca. 2 times higher in clouds than in false bottom and ribbons, which in turn hosted higher viral abundance than anoxic false bottom (Table 2). Virus:prokaryote ratios (VPR) ranged from 3.7 to 26.9 in macroflocs and clouds, respectively. Clouds and ribbons displayed significantly higher VPR than false bottom (26.9, 24.9 and 18.1, respectively). VPR in false bottom was significantly higher (ca. 2 to 5 times) than in all other aggregates (Tukey's test, $\mathrm{p}<0.05$ ). 


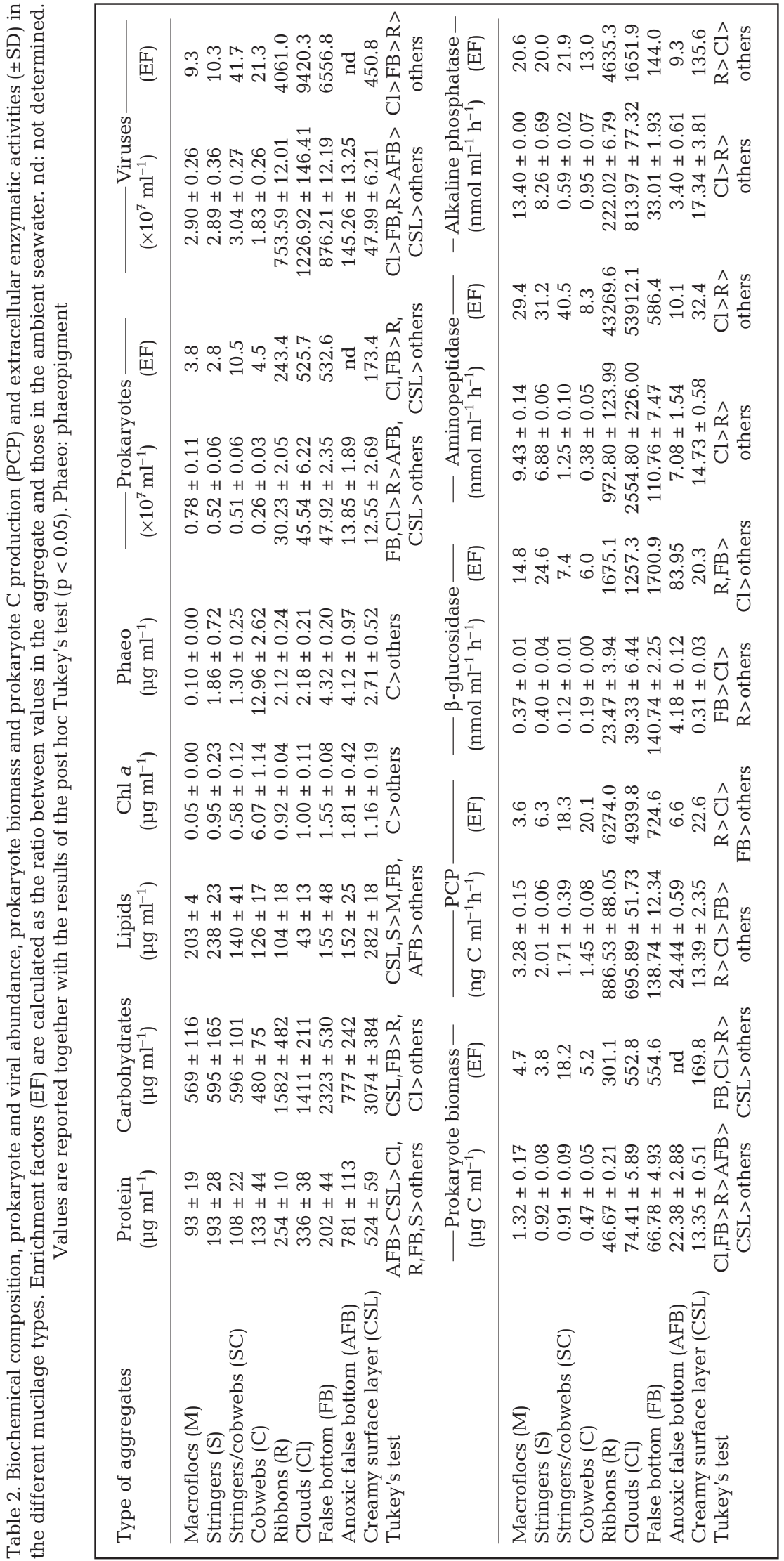

\section{Extracellular enzymatic activities}

The highest $\beta$-glucosidase activity was found in false bottom aggregates, in which values were 3.6 and 6 times higher than in clouds and ribbons, respectively (Table 2). The highest aminopeptidase and alkaline phosphatase activities were found in clouds (Table 2).

\section{Comparison between aggregates and the surrounding seawater}

EFs are reported in Table 2. Prokaryote and viral abundance in mucilages were, on average, 2 to 4 orders of magnitude higher than in the ambient seawater. The EFs of prokaryote and viral abundance significantly differed among mucilage types (ANOVA, $\mathrm{p}<0.05$ for all variables). In clouds and false bottom aggregates, prokaryote abundance and biomass were ca. 500 times higher than those in the ambient seawater and their EFs were significantly higher than in all other aggregates. Clouds hosted viral abundances hundreds of times higher than the ambient seawater. EFs of viral abundance in clouds were significantly higher than in false bottom, which in turn displayed higher EF than in ribbons and all other aggregates. The highest EFs of $\beta$-glucosidase activities and PCP were found in ribbons, clouds and false bottom. The EFs of aminopeptidase and alkaline phosphatase activities in ribbons and clouds were significantly higher than in all other aggregates.

\section{DISCUSSION}

Formation, life span and diagenesis of mucilage aggregates are supposed to be associated with changes in several microbial processes (e.g. substrate hydrolysis, prokaryote uptake and biomass 
production, substrate release). For instance, Azam et al. (1999) hypothesized that the formation of mucilage aggregates is initiated by the accumulation of DOM derived from the uncoupling between the intensive microbial degradation of aggregates and their limited utilization by heterotrophic prokaryotes. Studies on natural and experimentally produced aggregates have shown that prokaryote growth decreased from early colonized to aged aggregates, suggesting that PCP and degradation rates might depend upon the age of the aggregates (Alldredge \& Gotschalk 1990, MüllerNiklas et al. 1994, Unanue et al. 1998, Grossart \& Ploug 2000, 2001, Grossart et al. 2003). Recently, Del Negro et al. (2005) found higher prokaryote abundance, C production and enzymatic activities in early forming aggregates (cobwebs and ribbons) than in aged mucilage (clouds).

In the present study, we provide evidence that mucilage aggregates characterized by different shapes and putative age, based on the classification provided by Stachowitsch et al. (1990) and Precali et al. (2005), are characterized by evident dissimilarities in terms of organic matter quantity and biochemical composition, prokaryote abundance and production as well as of organic substrates degradation rates.

The MDS ordination carried out including only the biochemical variables of mucilage types allowed 2 major clusters to be identified (ANOSIM, p $<0.01$, Fig. 1A): (1) macroflocs, stringers, cobwebs and stringers/cobwebs; (2) false bottom, clouds, ribbons and creamy surface layer. This analysis also revealed that anoxic aggregates did not group within the 2 identified clusters. The types of mucilage clustering together for their biochemical composition represent different stages of the mucilage life span (Stachowitsch et al. 1990, Precali et al. 2005), with those included in Cluster 1 being putatively younger than those in Cluster 2. The carbohydrate and protein fractions increased from younger (Cluster 1) to aged (Cluster 2) aggregates, while the lipid fraction barely decreased with the mucilage ageing (Fig. 1B).

The carbohydrate fraction of aggregates increased in aged aggregates much faster than the protein pool, thus generating a shift in the overall biochemical composition, (e.g. from $65 \%$ of biopolymeric C in macroflocs to $80 \%$ in false bottom mucilage and creamy surface layers, Table 2). These results are consistent with the increase in the values of $\mathrm{C}: \mathrm{N}$ ratios observed in aged aggregates by other authors (Müller-Niklas et al. 1994, Giani et al. 2005). Only the anoxic aggregates that likely represented an exacerbated stage of the aged false bottom mucilage did not follow such a pattern, being characterized by the codominance of proteins and carbohydrates $(45 \%$ of biopolymeric C each, Fig. 1B). Shifts in the biochemi-
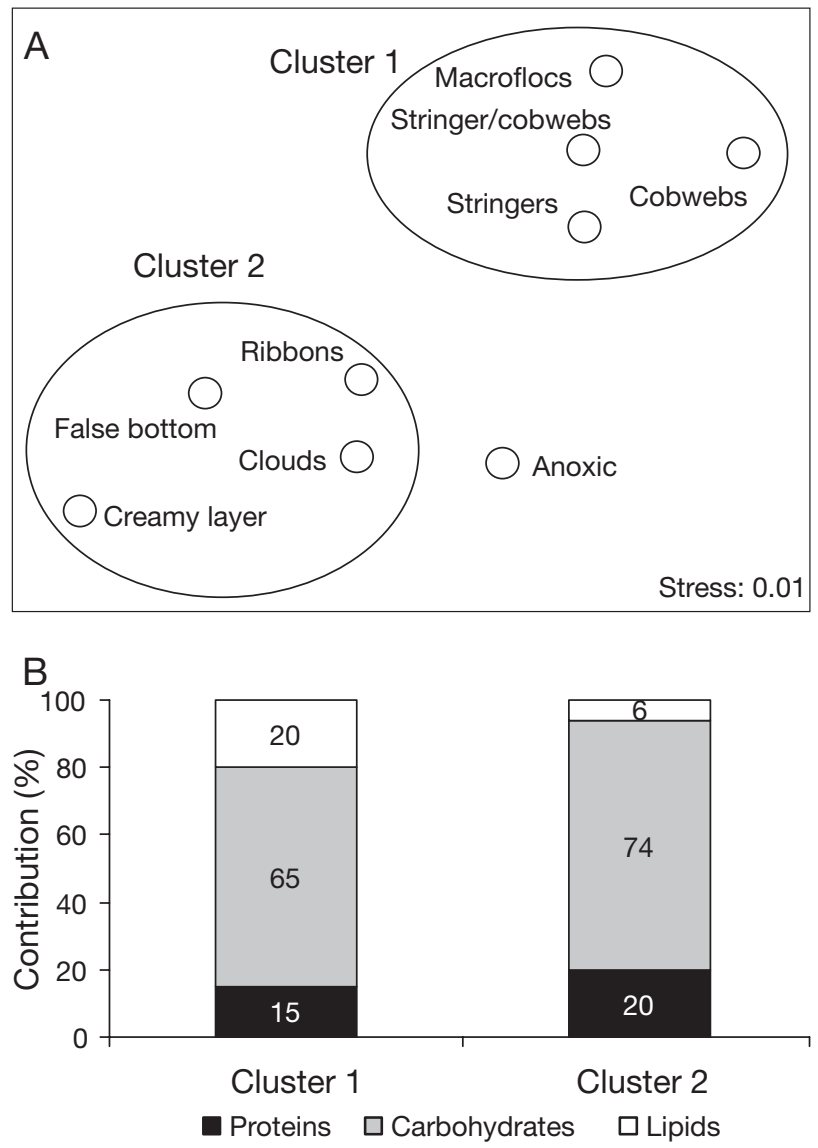

Fig. 1. (A) Multidimensional scaling representation, based on a set of biochemical parameters (proteins, carbohydrates, lipids, biopolymeric carbon, chl a and phaeopigments); (B) contribution of proteins, carbohydrate and lipids to biopolymeric carbon in the identified mucilage clusters. See Table 1 for mucilaginous aggregate types

cal composition of the different mucilage types were partially coupled with changes in the microbiological variables.

Prokaryote and viral abundance as well as values of PCP and enzymatic activities in aggregates varied within the range reported by Herndl (1988) and Del Negro et al. (2005) in the Adriatic Sea, and were comparable also with values reported from highly productive coastal benthic systems (Manini et al. 2003, Mei \& Danovaro 2004).

Multivariate analysis based on microbial variables (prokaryote abundance and biomass, viral abundance, PCP and extracellular enzymatic activities) allowed the different mucilage types to be pooled into 3 main clusters (Fig. 2): (1) macroflocs, stringers, stingers/ cobwebs and cobwebs; (2) ribbons, clouds and false bottom mucilages; and (3) anoxic false bottom and creamy surface layers (ANOSIM, p < 0.01). This clustering provides evidence of a clear shift in the 


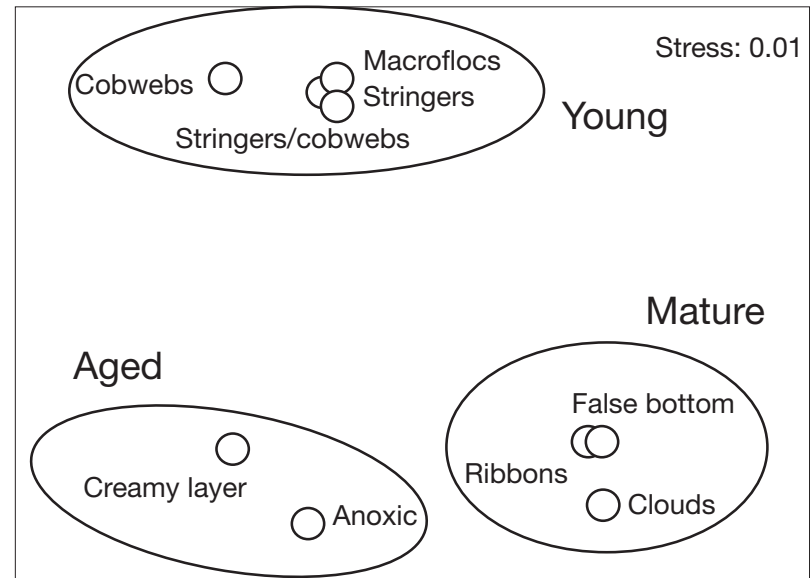

Fig. 2. Multidimensional scaling representation, based on a set of microbiological parameters (viral and prokaryote abundance, prokaryote biomass, carbon production, $\beta$-glucosidase, aminopeptidase and alkaline phosphatase activities). See Table 1 for mucilaginous aggregate types within young, mature and aged clusters

microbial processes during mucilage life span. Three mucilage ageing steps could be identified: (1) a young stage, characterized by low prokaryote and viral abundance and values of PCP and enzymatic activities; (2) a mature stage, characterized by highest values of all microbial parameters and by the highest EFs than in the other aggregates; (3) an aged stage, in which microbial variables tend to decrease to values similar to young-stage aggregates.

These 3 mucilage clusters were also characterized by significant differences in the fraction of enzymatically degraded C incorporated into prokaryote biomass, with values in the mature stage significantly lower than in the young and aged stage (Fig. 3A; ANOVA, $\mathrm{p}<0.05$; Tukey's test, $\mathrm{p}<0.05)$. This indicates that both young and aged stages of aggregates are characterized by a less pronounced imbalance between C degradation and incorporation into prokaryote biomass than the mature stage.

Previous studies hypothesized that the imbalance between $\mathrm{C}$ degradation and assimilation into prokaryote biomass, leading to the accumulation of DOC, could be a pre-requisite for mucilage development (Fonda-Umani et al. 2007). Our results suggest that such an imbalance, which also occurs within mature mucilage, might provide a potential self-maintaining mechanism for expanding mucilage lifespan.

An uncoupling between $\mathrm{C}$ degradation and incorporation into prokaryote biomass has been recently reported to occur also in the Antarctic sea ice during the spring bloom of sympagic algae (Guglielmo et al. 2000) and has been ascribed to different potential causes, such as the production of bacteriostatic compounds produced by microalgae (Raymond et al. 1994) or viral infection and high mortality of prokaryotes (Guglielmo et al. 2000).

In the present study, viral abundance co-varied with prokaryote abundance (Spearman, $\mathrm{r}=0.95, \mathrm{n}=27, \mathrm{p}<$ 0.01 ), and reached the highest values in mature mucilage. In addition, the VPR, representing a gross proxy of the probability of virus-host contact (Wommack \& Colwell 2000 and literature therein), was highest in mature mucilage (Fig. 3B; ANOVA, p $<0.01$; Tukey's test, $\mathrm{p}<0.05)$. Although further studies are needed for estimating the importance of virus-induced prokaryote mortality in mucilage, these results support the hypothesis that viruses can influence mucilage formation and persistence (Peduzzi \& Weinbauer 1993, Weinbauer \& Peduzzi 1995, Weinbauer et al. 1995, Baldi et al. 1997, Shibata et al. 1997).

Mucilage, once settled on the sea bottom, can promote the creation of hypoxic and/or anoxic conditions, which in turn affect benthic and epibenthic (including bentho-nekton species) organisms, and harm fisheries with important socioeconomic implications (Volterra et al. 1992, Danovaro et al. 2005).

The results presented here represent a further step towards the comprehension of the factors influencing mucilage life span in marine environments. However, further studies are needed to fully elucidate factors and environmental conditions which can promote a shorter life span and a faster dissolution of the mucilage, thus reducing its effect on coastal environments.

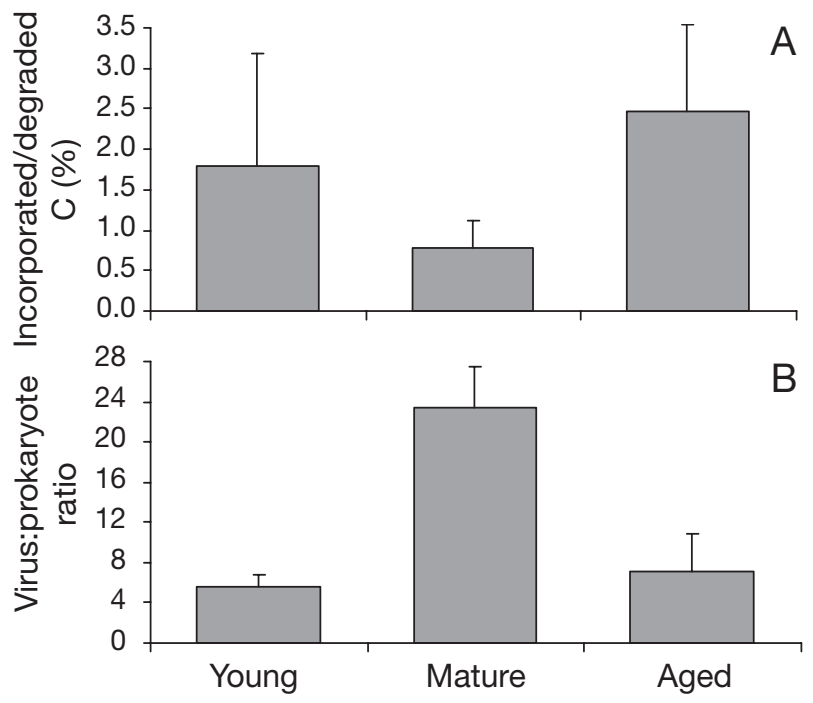

Fig. 3. (A) Fraction of enzymatically degraded C incorporated into prokaryote biomass and (B) virus:prokaryote abundance ratio in 3 mucilage stages $( \pm \mathrm{SD})$ 
Acknowledgements. The study was performed in the frame of the MAT Project (Mucilages in the Adriatic and Tyrrhenian Seas) coordinated by Istituto Centrale per la Ricerca Scientifica e Tecnologica Applicata al Mare (ICRAM) and financed by the Italian Ministry of Environment.

\section{LITERATURE CITED}

Alldredge AL, Gotschalk CC (1990) The relative contribution of marine snow of different origins to biological processes in coastal waters. Cont Shelf Res 10:41-58

Alldredge AL, Cowles TJ, MacIntyre S, Rines JEB and 6 others (2002) Occurrence and mechanism of formation of a dramatic thin layer of marine snow in a shallow Pacific fjord. Mar Ecol Prog Ser 233:1-12

Azam F (1997) Possible cause of massive mucilage production in the northern Adriatic Sea: a novel hypothesis. In: Nolan C (ed) Physical and biogeochemical processes of the Adriatic Sea: eutrophic limits of the northern Adriatic. The Adriatic Sea. European Communities Ecosystems Research Reports Series, Brussels

Azam F, Long RA (2001) Sea snow microcosms. Nature 414: 495-498

Azam F, Fonda Umani S, Funari E (1999) Significance of bacteria in the mucilage phenomenon in the northern Adriatic Sea. Ann Ist Super Sanità 35:411-419

Baldi F, Minacci A, Saliot A, Mejanelle L, Mozetic P, Turk V, Malej A (1997) Cell lysis and release of particulate polysaccharides in extensive marine mucilage assessed by lipid biomarkers and molecular probes. Mar Ecol Prog Ser 153:45-57

Bligh EG, Dyer W (1959) A rapid method for total lipid extraction and purification. Can J Biochem Physiol 37: 911-917

Bratbak G, Heldal M, Norland S, Thinsgstad TF (1990) Viruses as partners in spring bloom microbial trophodynamics. Appl Environ Microbiol 56:1400-1405

Crost RJ (ed) (1991) Microbial enzymes in aquatic environments. Springer-Verlag, Berlin

Danovaro R, Armeni M, Luna GM, Corinaldesi C and 10 others (2005) Exo-enzymatic activities and dissolved organic pools in relation with mucilage development in the Northern Adriatic Sea. Sci Total Environ 353:189-203

Degobbis D, Malej A, Fonda Umani S (1999) The mucilage phenomenon in the Northern Adriatic. A critical review of the past scientific hypotheses. Ann Ist Super Sanità 35: 373-382

Del Negro P, Crevatin E, Larato C, Ferrari C and 6 others (2005) Mucilage microcosms. Sci Total Environ 353: 258-269

Dubois M, Gilles KA, Hamilton JK, Rebers PA, Smith F (1956) Colorimetric method for determination of sugars and related substances. Anal Chem 28:350-356

Epstein SS, Rossel J (1995) Methodology of in situ grazing experiments: evaluation of a new vital dye for preparation of fluorescently labeled bacteria. Mar Ecol Prog Ser 128:143-150

Fabiano M, Pusceddu A (1998) Total and hydrolizable particulate organic matter (carbohydrates, proteins and lipids) at a coastal station in Terra Nova Bay (Ross Sea, Antarctica). Polar Biol 19:125-132

Fichez R (1991) Composition and fate of organic matter in submarine cave sediments; implications for the biogeochemical cycle of organic carbon. Oceanol Acta 14:369-377

Fogg GE (1995) Some speculations on the nature of the pelagic mucilage community of the northern Adriatic Sea.
Sci Total Environ 165:59-63

Fonda Umani S, Del Negro P, Larato C, De Vittor C and 5 others (2007) Major inter-annual variations in microbial dynamics in the Gulf of Trieste (northern Adriatic Sea) and their ecosystem implications. Aquat Microb Ecol 46: $163-175$

Fry JC (1988) Determination of biomass. In: Austin B (ed) Methods in aquatic bacteriology. John Wiley \& Sons, New York, p 27-72

Gerchacov SM, Hatcher PG (1972) Improved technique for analysis of carbohydrates in sediments. Limnol Oceanogr 17:938-943

Giani M, Cicero AM, Savelli F, Bruno M, Donati G, Farina A, Veschetti E, Volterra L (1992) Marine snow in the Adriatic Sea: a multifactorial study. Sci Total Environ Suppl: 539-549

Giani M, Berto D, Zangrando V, castelli S, Sist P, Urbani R (2005) Chemical characterization of different typologies of mucilaginous aggregates in the Northern Adriatic Sea. Sci Total Environ 353:232-246

Gotsis-Skretas O (1995) Mucilage appearances in Greek waters during 1982-1994. Sci Total Environ 165:229-230

Grossart HP, Ploug H (2000) Bacterial production and growth efficiencies: direct measurements on riverine aggregates. Limnol Oceanogr 45:436-445

Grossart HP, Ploug H (2001) Microbial degradation of organic carbon and nitrogen on diatom aggregates. Limnol Oceanogr 46:267-277

Grossart HP, Hietanen S, Ploug H (2003) Microbial dynamics on diatom aggregates in Øresund, Denmark. Mar Ecol Prog Ser 249:69-78

Guglielmo L, Carrada GC, Catalano G, Dell'Anno A and 5 others (2000) Structural and functional properties of sympagic communities in the annual sea ice at Terra Nova Bay (Ross Sea, Antarctica). J Polar Biol 23:137-146

Hartree EF (1972) Determination of protein a modification of the Lowry method that gives a linear photometric response. Anal Biochem 48:422-427

Herndl GJ (1988) Ecology of amorphous aggregations (marine snow) in the northern Adriatic Sea: II. Microbial density and activity in marine snow and its implication to overall pelagic processes. Mar Ecol Prog Ser 48:265-275

Herndl GJ, Peduzzi P (1988) Ecology of amorphous aggregations (marine snow) in the Northern Adriatic sea: I general considerations. PSZN I: Mar Ecol 9:79-90

Herndl GJ, Karner M, Peduzzi P (1992) Floating mucilage in the Northern Adriatic Sea: the potential role of a microbial ecological approach to solve the 'mystery'. Sci Total Environ Suppl:525-538

Hoppe HG (1993) Use of fluorogenic model substrates for extracellular enzyme activity (EEA) of bacteria. In: Kemp PF, Sherr BF, Sherr EB, Cole JJ (eds) Handbook of methods in aquatic microbial ecology. Lewis, Boca Raton, FL, p 423-431

Innamorati M (1995) Hyperproduction of mucilages by micro and macro algae in the Tyrrhenian Sea. Sci Total Environ 165:65-81

Kiørboe T (2001) Formation and fate of marine snow: smallscale processes with large-scale implications. Sci Mar 65:57-71

Kirchman DL (1993) Leucine incorporation as a measure of biomass production by heterotrophic bacteria. In: Kemp PF, Sherr BF, Sherr EB, Cole JJ (eds) Handbook of methods in aquatic ecology. Lewis Publishers, Boca Raton, FL, p 509-512

Lorenzen C, Jeffrey J (1980) Determination of chlorophyll in sea water. UNESCO Tech Pap Mar Sci 35:1-20

Manini E, Fiordelmondo C, Gambi C, Pusceddu A, Danovaro 
R (2003) Benthic microbial loop functioning in coastal lagoons: a comparative approach. Oceanol Acta 26:27-38

Marsh JB, Weinstein WJ (1966) A simple charring method for determination of lipids. J Lipid Res 7:574-576

Mei ML, Danovaro R (2004) Virus production and life strategies in aquatic sediments. Limnol Oceanogr 49:459-470

Müller-Niklas G, Schuster S, Kaltenböck E, Herndl GJ (1994) Organic content and bacterial metabolism in amorphous aggregations of the northern Adriatic Sea. Limnol Oceanogr 39:58-68

Noble R, Fuhrman JA (1998) Use of SYBR Green I for rapid epifluorescence counts of marine viruses and bacteria. Aquat Microb Ecol 14:113-118

Pajdak-Stós A, Fialkowska E, Fyda J (2001) Phormidium autumnale (Cyanobacteria) defense against three ciliate grazer species. Aquat Microb Ecol 23:237-244

Palumbo AV, Ferguson RL, Rublee PA (1984) Size of suspended bacterial cells and association of heterotrophic activity with size fractions of particles in estuarine and coastal waters. Appl Environ Microbiol 48:157-164

Peduzzi P, Weinbauer MG (1993) Effect of concentrating the virus-rich $2-200 \mathrm{~nm}$ size fraction of seawater on the formation of algal flocs (marine snow). Limnol Oceanogr 38:1562-1565

Precali R, Giani M, Marini M, Grilli F, Ferrari CR, Pečar O, Paschini E (2005) Mucilaginous aggregates in the northern Adriatic in the period 1999-2002: typology and distribution. Sci Total Environ 353:10-23

Pusceddu A, Dell'Anno A, Danovaro R, Manini E, Sarà G, Fabiano M (2003) Enzymatically hydrolyzable protein and carbohydrate sedimentary pools as indicators of the trophic state of detritus sink systems: a case study in the Mediterranean coastal lagoon. Estuaries 26:641-650

Raymond JA, Sullivan CW, DeVries AL (1994) Release of an ice-active substance by Antarctic sea ice diatoms. Polar Biol 14:71-75

Rice DL (1982) The detritus nitrogen problem: new observations and prospectives from organic geochemistry. Mar Ecol Prog Ser 9:153-162

Editorial responsibility: Josep Gasol,

Barcelona, Spain
Riebesell U (1992) The formation of large marine snow and its sustained residence in surface waters. Limnol Oceanogr 37:63-76

Shibata A, Kogure K, Koike I, Ohwada K (1997) Formation of submicron colloidal particles from marine bacteria by viral infection. Mar Ecol Prog Ser 155:303-307

Simon M, Grossart HP, Schweitzer B, Ploug H (2002) Microbial ecology of organic aggregates in aquatic ecosystems. Aquat Microb Ecol 28:175-211

Smith DC, Azam F (1992) A simple, economical method for measuring bacterial protein synthesis rates in seawater using ${ }^{3} \mathrm{H}$ leucine. Mar Microb Food Webs 6:107-114

Stachowitsch M, Fanuko N, Ritcher M (1990) Mucus aggregates in the Adriatic Sea: an overview of stages and occurrences. PSZN I: Mar Ecol 11:327-350

Steinberg DK, Silver MW, Pilskaln CH (1997) Role of mesopelagic zooplankton in the community metabolism of giant larvacean house detritus in Monterey Bay, California, USA. Mar Ecol Prog Ser 147:167-179

Unanue M, Azua I, Arrieta JM, Labirua-Iturburu A, Egea L, Irriberri J (1998) Bacterial colonization and ectoenzymatic activity in phytoplankton-derived model particles. cleavage of peptides and uptake of amino acids. Microb Ecol 35:136-146

Volterra L, Aulicino FA, Bonadonna L, De Mattia M, Di Girolamo I, Liberti R, Mancini L (1992) Microbial analysis of Adriatic Sea mucilage. In: Vollenweider RA, Marcetti R, Viviani R (eds) Marine coastal eutrophication. Elsevier Science Publishers, Amsterdam, p 551-556

Weinbauer M, Peduzzi P (1995) Significance of viruses versus heterotrophic nanoflagellates for controlling bacterial abundance in the northern Adriatic Sea. J Plankton Res $17: 1851-1854$

Weinbauer MG, Fuks D, Puskaric S, Peduzzi P (1995) Diel, seasonal, and depth-related variability of viruses and dissolved DNA in the northern Adriatic Sea. Microb Ecol 30:25-41

Wommack KE, Colwell RR (2000) Virioplankton: viruses in aquatic ecosystems. Microbiol Mol Biol Rev 64:69-114

Submitted: December 28, 2006; Accepted: June 29, 2007 Proofs received from author(s): August 23, 2007 